\title{
Oxygen isotopic paleotemperatures across the Runangan-Whaingaroan (Eocene-Oligocene) boundary in a New Zealand shelf sequence
}

\author{
DAVID A. BURNS \\ CAMPBELL S. NELSON \\ Department of Earth Sciences \\ University of Waikato \\ Private Bag \\ Hamilton, New Zealand
}

\begin{abstract}
Oxygen isotopic compositions of the tests of mainly benthic foraminifera, from sections of conformable Late Eocene (Runangan) to Early Oligocene (Whaingaroan) shelf mudstones, at both Cape Foulwind and Port Elizabeth, western South Island, indicate that shelf sea paleotemperatures followed the global open-ocean trend towards a Paleogene minimum near the Eocene-Oligocene boundary. Throughout the latest Eocenc, temperatures declined steadily by $3^{\circ} \mathrm{C}$, showed a temporary minor warming at the Eocene-Oligocene boundary, dropped sharply by $2^{\circ} \mathrm{C}$ in the Early Oligocene, and ameliorated significantly later in the Early Oligocene. The qualitative temperature trends for New Zealand shelf waters at this time are similar to those inferred from earlier paleontologic syntheses and limited oxygen isotopic work, but involve a range of temperatures within the warm and cool temperate climatic zones and an absolute temperature depression across the Eocene-Oligocene boundary of only $5^{\circ} \mathrm{C}$ (from about 17 to $12^{\circ} \mathrm{C}$ ). Results are consistent with isotopic paleotemperatures determined from deep-sea sediment cores south of New Zealand where the cooling is inferred to mark the onset of production of Antarctic bottom waters at near-freezing temperatures.
\end{abstract}

Keywords paleotemperatures; oxygen isotopes; Eocene; Oligocene; Runangan Stage; Whaingaroan Stage; foraminifera; shelf sediments

\section{INTRODUCTION}

Attempts to reconstruct the Cenozoic climate of the New Zealand region have been based on paleontologic, oxygen isotopic, and, more rarely, lithologic data (e.g., Fleming 1962, 1979; Hornibrook 1967, 1971; Devereux 1967a; Dawson 1968; Shackleton \& Kennett 1975). Despite early conflicting opinions of

Received 27 March 1981, accepted 27 October 1981 the climate during the Late Eocene and Oligocene (Fig. 1; Dawson 1968), an apparently distinctive feature of this interval is the sharp drop in sea temperatures across the Runangan-Whaingaroan boundary-adopted as the Eocene-Oligocene boundary in New Zealand following Srinivasan \& Vella (1975) and Stevens (1980) - suggested by both the total paleontologic evidence (Hotnibrook 1971) and the oxygen isotopic record of fossil materials (Devereux 1967a). The magnitude and timing of the temperature drop, and indeed its reality, have nevertheless remained controversial topics (Hornibrook 1971, 1978; Fleming 1979), although several workers (e.g., Margolis \& Kennett 1971; Berggren 1972; Berggren \& van Couvering 1974) appear to have accepted without question the isotopic curve of Devereux (1967a) which shows a very sudden change from subtropical to cool temperate conditions at this time, involving a dramatic fall in temperature of about $9^{\circ} \mathrm{C}$ (Fig. 1, curve $G$ ). However, closer inspection of Devereux' (1967a) isotopic data shows that of the 11 samples analysed for the Runangan and Whaingaroan Stages across the Eocene-Oligocene boundary, 6 were whole rock bryozoan limestones and 3 were oyster shells, sample types normally regarded as unsuitable for reliable determinations of marine paleotemperatures (Savin et al. 1975), and that coexisting samples within each stage record a very wide range of paleotemperatures, covering about $9^{\circ} \mathrm{C}$ (see Fig. 4). Moreover, the ages for individual samples span either a whole stage or half a stage, and therefore provide extremely poor time resolution, particularly as the combined absolute time interval covered by the Runangan and Whaingaroan Stages amounts to at least $10 \mathrm{~m} . \mathrm{y}$. (Stevens 1980). These kinds of considerations make it difficult to accept uncritically Devereux' positioning of the New Zealand isotopic paleotemperature curve across the interval spanning the Runangan and Whaingaroan Stages (Fig. 1, curve $\mathrm{G}$ ).

Oxygen isotopic ratios of benthic and planktic foraminifera presently provide the least equivocal data concerning the temperatures of bottom and near-surface waters respectively (Hecht 1976). Thus, in an attempt to define more closely the paleoclimatic history of the Late Eocene and Early Oligocene in New Zealand, oxygen isotopic analyses have been made for foraminiferal concentrates from 2 stratigraphic sections spanning this period. 


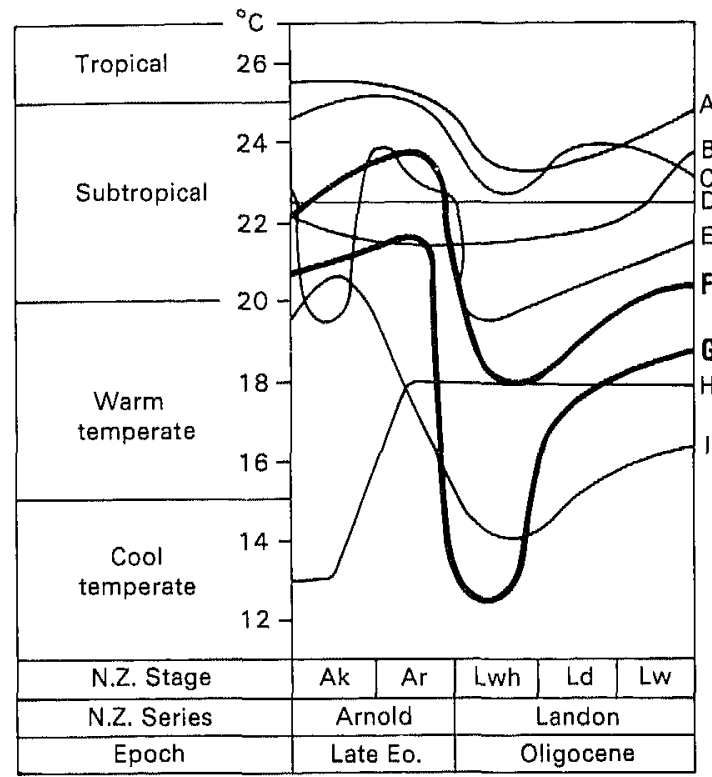

Fig. 1 Selection of New Zealand climate curves proposed for Late Eocene-Oligocene times (normalised to the latitude of Wellington at $41^{\circ} \mathrm{S}$ ). Curves are based on the following criteria: $A$ and $D$, maximum and minimum curves respectively for larger foraminifera (Hornibrook 1968); B, scleractinian corals (Keyes 1968); C, Mollusca (Beu \& Maxwell 1968); E, planktic foraminifera (Jenkins 1968); F, total paleontologic evidence (Hornibrook 1971) $G$, oxygen isotopes (Devereux 1967a); H, spores and pollens (McQueen et al. 1968); I, calcareous nannoplankton (Edwards 1968b). Note that New Zealand stages (Ak, Kaiatan; Ar, Runangan; Lwh, Whaingaroan; Ld, Duntroonian; and Lw, Waitakian) are given equal weight and thus do not adequately convey time.

\section{EXPERIMENTAL TECHNIQUES}

Analytical methods are described fully by Burns (1980) and only a brief summary of procedures is given here. Disaggregated samples of mudstone were repeatedly washed through $125-\mu \mathrm{m}$-mesh sieves and vibrated in an ultrasonic bath to obtain the coarser than $125 \mu \mathrm{m}$ fraction for analysis. Airdried fractions were passed through a Frantz magnetic separator ( $2 \mathrm{~A}$ current with $20^{\circ}$ forward and side angles) which effectively separated relatively clean foraminiferal tests (nonmagnetic) from those whose chambers still retained mudstone impurities (magnetic). The nonmagnetic fraction was then further purified by floating of empty foraminiferal tests in a carbon tetrachloride heavy liquid separation column. Foraminiferal subsamples (Table 1) were concentrated by hand-picking under a binocular microscope, at which stage individual tests were visually checked for overgrowths, recrystallisation, discoloration, and choked-up apertures.

Samples of about $0.3 \mathrm{mg}$ were vacuum roasted at $400^{\circ} \mathrm{C}$ to remove organic matter, crushed to powder with a glass rod, and decomposed by reaction with $100 \%$ orthophosphoric acid at $50^{\circ} \mathrm{C}$, following the technique of Shackleton (1974). The carbon dioxide and water produced in the reaction chamber were quickly separated from each other by means of a series of slush traps containing a mixture of liquid nitrogen and methanol, and the carbon dioxide was passed directly into the cold finger inlet of a VG Micromass $602 \mathrm{C}$ mass spectrometer. Derivation of oxygen isotopic values from the mass spectrometer data was made using the procedures of Mook (1968) as modified by Grinstead (1977). Results are reported as per mille $(\%)$ deviations from the international PDB standard. Data were related to PDB by frequent analyses of the secondary international standards, NBS -20 (Craig 1957) and TKL (Blattner \& Hulston 1978), and the "house" standards WLS and WLS-1 (Burns 1980). The standard deviation from the mean value for replicate analyses of standards was about $0.18 \%$; for foraminiferal samples the standard deviation was usually less than this value (see Table 1).

\section{SAMPLES ANALYSED AND CONSTRAINTS OF ISOTOPIC DATA}

Continuously exposed cliff sections of conformable Late Eocene-Early Oligocene calcareous mudstones of the Kaiata Formation (Officers of the Geological Survey 1974) occur on the coastline at Port Elizabeth and Cape Foulwind, western South Island, New Zealand (Fig. 2). The lithology, micropaleontology, and age of these sections have been described in detail by Srinivasan (1965) Officers of the Geological Survey (1974), and Nathan $(1975,1978)$, and discussed by Srinivasan \& Vella (1975) who provided small splits of their samples for this project. Foraminifera for isotopic analysis were concentrated from 17 of these samples (Fig. 2 and Table 1). Benthic foraminifera, dominated by specimens of Uvigerinidae, Nodosariidae, and Cibicides, are more abundant than planktic forms in all samples. The small size of bulk samples generally precluded the concentration of monospecific assemblages. Collections of benthic assemblages, the principal forms analysed, were related at the family and, less commonly, at the generic level (Table 1).

It is important that the specimens chosen for paleotemperature determinations deposited their tests in isotopic equilibrium with the surrounding water (Hecht 1976). Wherever possible, species of 
Table 1 Oxygen isotopic compositions and derived paleotemperatures of foraminiferal assemblages from Cape Foulwind and Port Elizabeth.

*Anomalous result because of calcite overgrowths.

Sample (N.2.
Fossil Rec.
File No.)

\begin{tabular}{|c|c|c|c|c|}
\hline \multicolumn{5}{|c|}{$\begin{array}{l}\text { Cape Foulwind } \\
(523 / \mathrm{E}-)\end{array}$} \\
\hline 522 & & Mixed Nodosariacea & $-0.99 \pm 0.04$ & 16.9 \\
\hline \multirow[t]{2}{*}{536,} & split $A$ & Mixed Nodosariacea & $-0.23 \pm 0.09$ & 13.6 \\
\hline & split $B$ & Melonis dorreen $i$ & $-0.46 \pm 0.04$ & 14.6 \\
\hline 537 & & Mixed Nodosarifide and Trifarina & $-0.57 \pm 0.09$ & 15.0 \\
\hline \multirow[t]{2}{*}{538} & $\begin{array}{l}\text { split A } \\
\text { split B }\end{array}$ & $\begin{array}{l}\text { Mixed Nodosariida } \\
\text { Trifarina and Rectuvigerina }\end{array}$ & $-0.20 \pm 0.16$ & 13.4 \\
\hline & & striatissima & $-0.15 \pm 0.08$ & 13.2 \\
\hline \multirow{2}{*}{539} & split A & Mixed Cibiaides & $-0.17 \pm 0.10$ & 13.3 \\
\hline & split B & Mixed Trifarina & $-0.32 \pm 0.13$ & 14.0 \\
\hline 540 & & Mixed Cibicides & $-0.29 \pm 0.11$ & 13.8 \\
\hline 543 & & Mixed Nodosariacea & $-0.23 \pm 0.18$ & 13.6 \\
\hline 544 & & $\begin{array}{l}\text { Mixed Nodosariidae, Uvigerinidae } \\
\text { and Cibicides }\end{array}$ & $-0.03 \pm 0.18$ & 12.8 \\
\hline \multirow[t]{2}{*}{545} & $\begin{array}{l}\text { split A } \\
\text { split B }\end{array}$ & $\begin{array}{l}\text { Mixed Nodosariidae } \\
\text { Rectuvigerina striatissima, }\end{array}$ & $-0.35 \pm 0.15 *$ & 14.1 \\
\hline & & Trifarina and Cibicides & $+0.20 \pm 0.12$ & 11.8 \\
\hline 548 & & Mixed Uvigerinidae and cibicides & $-0.51 \pm 0.08$ & 14.8 \\
\hline 549 & & Rectuvigerina striatissima & $-1.11 \pm 0.11$ & 17.4 \\
\hline \multicolumn{5}{|c|}{$\begin{array}{l}\text { Port Elizabeth } \\
\text { (S44/f-) }\end{array}$} \\
\hline 957 & & Mixed Nodosariidae & $-0.56 \pm 0.08$ & 15.0 \\
\hline 958 & & Mixed Nodosaridae & $-0.40 \pm 0.04$ & 14.3 \\
\hline & split A & Mixed nodosariidae & $-0.80 \pm 0.20$ & 16.0 \\
\hline & split $B$ & Globigerapsis index & $-0.78 \pm 0.07$ & 16.0 \\
\hline 960 & & $\overline{\text { Mixed Lenticulina }}$ & $-2.84 \pm 0.03^{*}$ & 25.3 \\
\hline \multirow[t]{2}{*}{ 961, } & split $A$ & Mixed Lenticulina & $-0.20 \pm 0.22$ & 13.5 \\
\hline & split B & Mixed planktonics & $-0.42 \pm 0.18$ & 14.4 \\
\hline 962 & & $\begin{array}{l}\text { Mixed Nodosariidae and Rectuvigerina } \\
\text { striatissima }\end{array}$ & $-1,28$ & 18.7 \\
\hline
\end{tabular}

Rectuvigerina and Trifarina from the family Uvigerinidae were analysed, as Shackleton (1974) has demonstrated that the genus Uvigerina attains isotopic equilibrium with ocean water. Cibicides probably dóes likewise (Shackleton 1967), but the isotopic characteristics of the Nodosariidae are unknown.

It is possible to detect specimens that do not deposit their calcite in isotopic equilibrium with seawater by analysing coexisting species. A marked difference in isotopic composition between pairs of a group suggests that the oxygen isotopic ratio of one or other of the pairs has probably been influenced by biological fractionation or post-depositional alteration. Analysis of coexisting benthic assemblages in 4 samples from the Cape Foulwind section (labelled split A \& B in Table 1) shows that the $\delta^{18} \mathrm{O}$ difference for 3 sets of pairs is less than $0.23 \%$ $\left(\sim 1^{\circ} \mathrm{C}\right)$, which constitutes an acceptable experimental error for the oxygen isotopic technique. However, for sample S23/f545* the range of $0.55 \%$ o

*New Zealand Fossil Record File number is large and suggests that foraminifera have either undergone post-depositional isotopic exchange or that 1 or more of the species present did not deposit calcite in isotopic equilibrium with seawater. Reexamination of sample $\$ 23 / f 545$, split $A$, indicated that some of the large specimens of Nodosariidae possibly had calcite overgrowths within their chambers, a feature which probably also accounts for the anomalous isotopic results of the Lenticulina specimens in sample S44/f960 (see Table 1). In such samples the correct isotopic value would tend towards the more positive number, as postdepositional alteration usually lowers the ${ }^{18} \mathrm{O}$ content, resulting in erroneously high paleotemperatures (Savin 1977).

From the evidence given in Table 1, together with the data of Shackleton $(1967,1974)$, the tests of benthic foraminifera concentrated from the 2 stratigraphic sections are considered to have been deposited under conditions approaching isotopic equilibrium (cf. also Smith \& Emiliani 1968; Savin et al. 1975). 


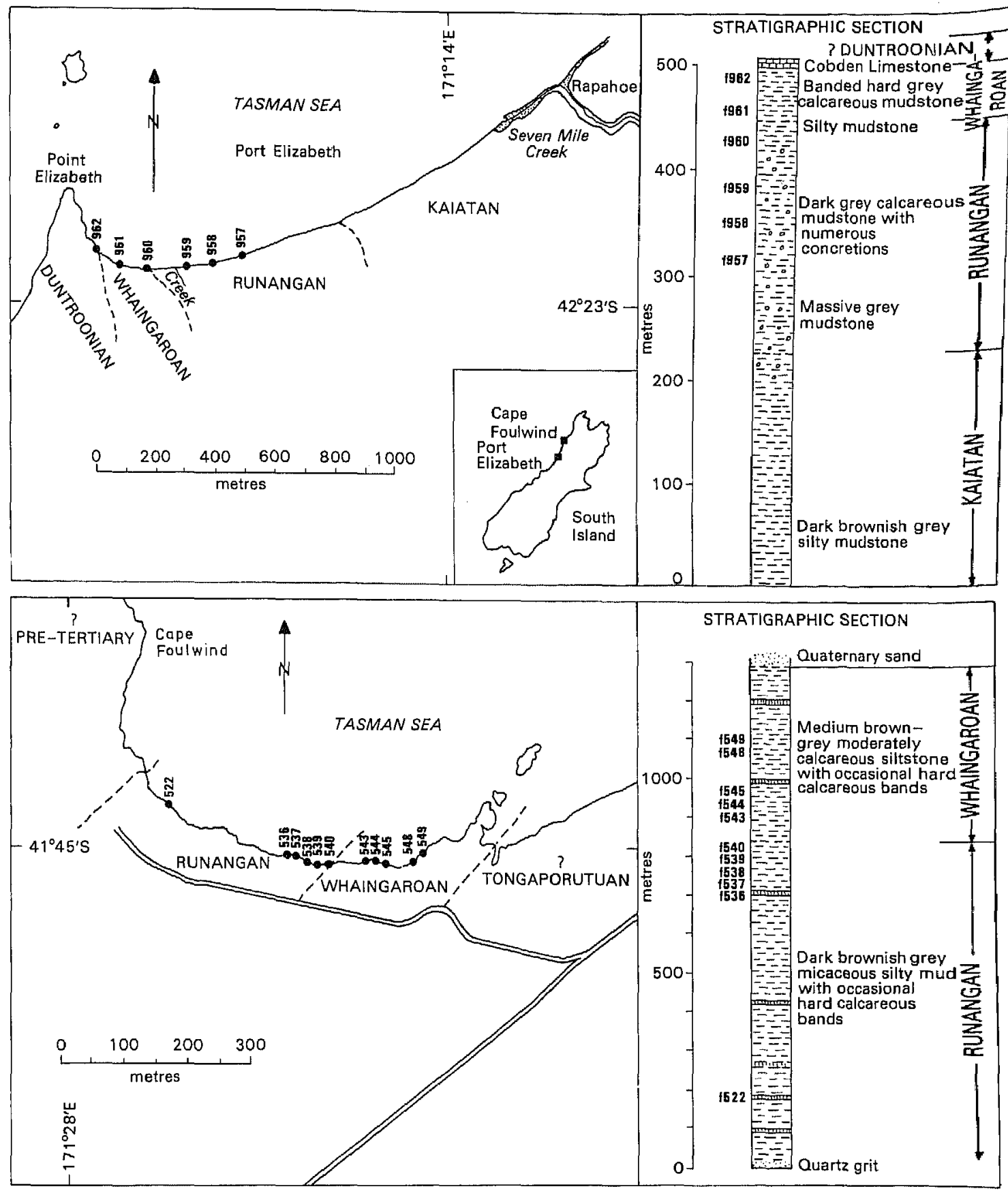

Fig. 2 Locality maps of Port Elizabeth and Cape Foulwind sections showing the locations and stratigraphic positions of microfossil samples used for isotopic analyses (adapted from Srinivasan \& Vella 1975). The sample numbers refer to localities registered in the New Zealand Fossil Record File prefixed S23/f-(Cape Foulwind) and S44/f-(Port Elizabeth) respectively. 
A further constraint on the usefulness of species in oxygen isotopic analysis concerns some knowledge of the depth habitat of the specimens, so that derived paleotemperatures can be related to surface water temperatures. Officers of the Geological Survey (1974) and Srinivasan \& Vella (1975) concluded from paleontologic evidence that the mudstones in the Port Elizabeth and Cape Foulwind sections were deposited in shelf water depths. On this basis, the benthic foraminifera should yield paleotemperatures close to those determined for coexisting planktic species. Two samples (S44/f959, S44/f961) from the Port Elizabeth section contained sufficient numbers of well preserved planktic foraminifera for analysis, and their isotopic compositions are close to those of the coexisting benthic assemblages (Table 1). Thus, growth temperatures calculated from the isotopic compositions of the benthic foraminifera appear to provide reasonable estimates of surface water temperatures during deposition of these mudstones, although it is probable that the derived surface temperatures are essentially minimum (cf., Savin et al, 1975).

An isotopic temperature is a function of the difference between the $\delta^{18} \mathrm{O}$ of the shell carbonate and the $\delta^{18} \mathrm{O}$ of the water in which the shell grew. In this study the isotopic temperature has been calculated using the expression of Shackleton (1974): $\mathrm{PDB})^{2}$

$\left.T^{\circ} \mathrm{C}\right)=16.9-4.38\left(\delta^{18} \mathrm{O} \mathrm{PDB}\right)+0.10\left(\delta^{18} \mathrm{O}\right.$

where $\delta^{18} \mathrm{O}=\delta^{18} \mathrm{O}$ (carbonate) $-\delta^{18} \mathrm{O}$ (water). The $\delta^{18} \mathrm{O}$ (water) value has varied with time, especially as a consequence of worldwide fluctuations in the volume of continental ice (Shackleton \& Kennett 1975). Prior to the buildup of the East Antarctic Ice Sheet in the Middle Miocene (Kennett et al. 1975; Shackleton \& Kennett 1975) the ${ }^{18} \mathrm{O}$ composition of the oceans would have been much lower than the present average value of about $-0.28 \%$ PDB (Craig 1965). Craig (1965) estimated a pre-Middle Miocene ocean isotopic composition of $-0.80 \%$ PDB, a value accepted by Savin et al. (1975) in deriving their Early Tertiary marine paleotemperatures. More recently, Shackleton \& Kennett (1975) suggested that the true value was probably closer to $-1.20 \%$ PDB. Rather than arbitrarily choosing one or the other value as being correct, we have taken the mean value of $-1.00 \%$ PDB as approximating the isotopic composition of Early Miocene oceans. Accordingly, the paleotemperatures reported here are within $1^{\circ} \mathrm{C}$ of what the values would be if either of the procedures of Savin et al. (1975) or Shackleton \& Kennett (1975) were used.

\section{RESULTS}

The oxygen isotopic compositions $\left(8^{18} \mathrm{O} \mathrm{PDB}\right)$ and derived isotopic temperatures of the foraminiferal assemblages from the Port Elizabeth and Cape Foulwind sections are listed in Table 1 and plotted in Fig. 3. The horizontal axis of the graph in Fig. 3 cannot be constructed presently using an absolute time scale, but it is plotted by assuming a constant rate of sedimentation over the time interval represented by the equally spaced samples of Srinivasan \& Vella (1975) within each of the Runangan and Whaingaroan Stages at the Cape Foulwind section, and superimposing upon this scale age correlative samples from Port Elizabeth, using their benthic foraminiferal zonation scheme.

The paleotemperature curves for the 2 sections show the same general trends: a steady decline in temperatures over a $2 \mathrm{~m} . \mathrm{y}$. period through the Runangan to the earliest Whaingaroan, followed by climatic amelioration over a further $2 \mathrm{~m}$.y. period higher in the Lower Whaingaroan (Globigerina angiporoides zone of Hornibrook \& Edwards (1971)) to a temperature similar to that occurring in the early Runangan. Between samples $\$ 44 / f 961$ and $\mathrm{S} 44 / \mathrm{f} 962$ the shape of the Port Elizabeth curve is uncertain as only 1 mass spectrometric analysis is available for sample S44/f962; the Cape Foulwind data are far more complete over this interval. The overall climatic deterioration from the early Runangan to the early Whaingaroan involves an absolute temperature drop of about $5.5^{\circ} \mathrm{C}$, covering the range $17-11.5^{\circ} \mathrm{C}$, and a shift from warm temperate to cool temperate climatic conditions. A feature of both curves is the apparently small, shortlived temperature amelioration in the latest Runangan. The slight displacement in the timing and duration of this amelioration between the 2 curves is presumably an artefact of the inability to correlate exactly between sections the samples from within the Bolivina (Latibolivina) pontis biostratigraphic zone, coupled with the larger sampling interval for the Port Elizabeth site.

\section{DISCUSSION}

Despite our earlier criticism of the evidence on which Devereux (1967a) based his paleotemperature curve for the Whaingaroan Stage, it is clear that his suggested fall in sea surface temperatures across the Runangan-Whaingaroan (Eocene-Oligocene) boundary is substantiated by our isotopic data. However, to compare directly Devereux' absolute temperature curve with ours it is necessary to apply 2 amendments to his data. Firstly, $1^{\circ} \mathrm{C}$ must be subtracted from his curve to account for the latitudinal difference between the Cape Foulwind 


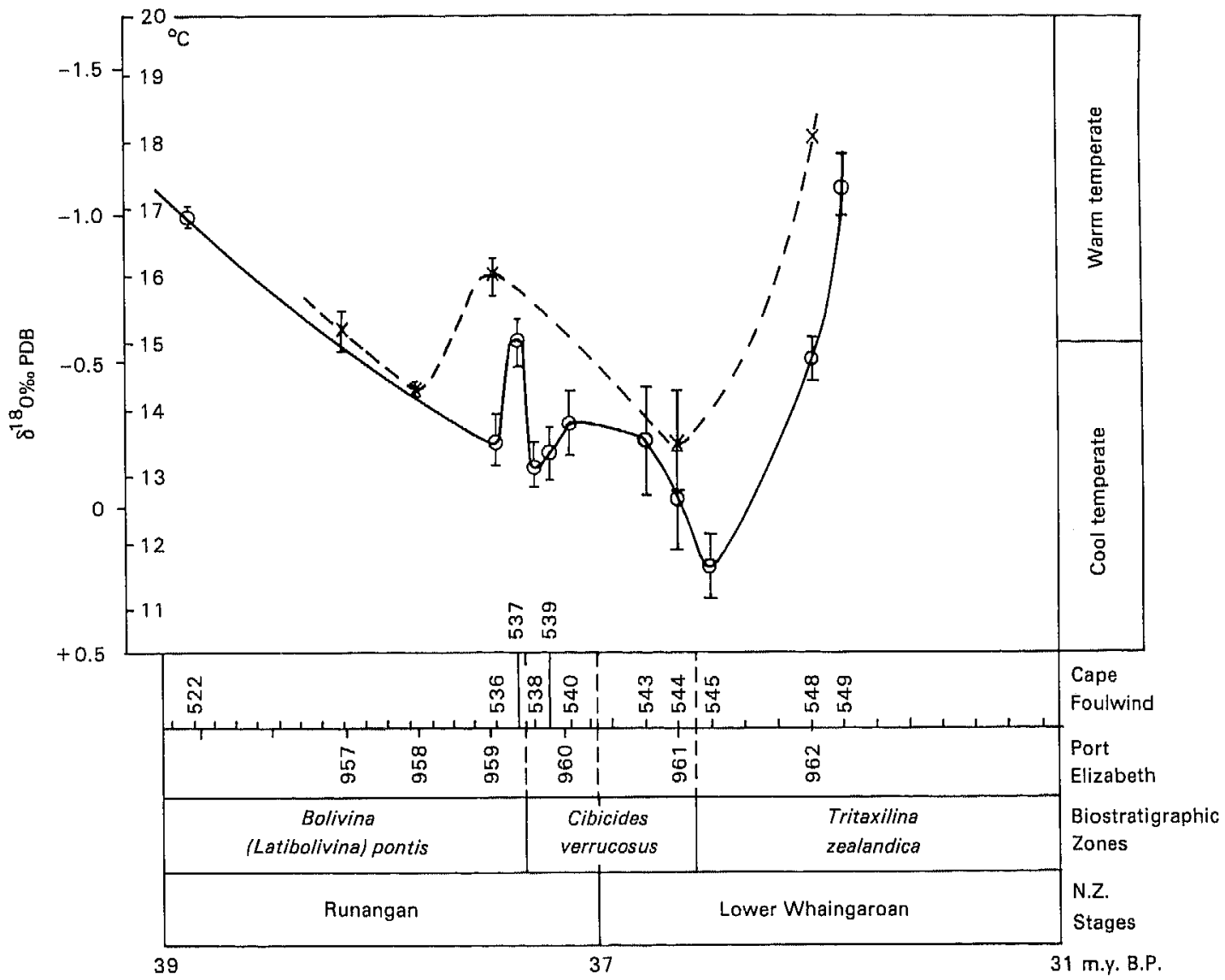

Fig. 3 Oxygen isotopic compositions of foraminiferal assemblages and derived paleotemperature curves across the Runangan-Whaingaroan (Eocene-Oligocene) boundary for samples from the Port Elizabeth (broken curve) and Cape Foulwind (solid curve) sections. Vertical bars represent standard deviation. Foraminiferal zonation scheme after Srinivasan \& Vella (1975). Note that the absolute time covered by the Runangan and Lower Whaingaroan Stage segments is about 2 and $6 \mathrm{~m}$.y. respectively (from Stevens 1980) so that the temperature decline recorded from samples $\mathrm{S} 23 / \mathrm{f} 522$ to 545 spans, in fact, a similar or shorter period of time as the interval of temperature amelioration between samples S23/5545 and 549.

region and Wellington, to which Devereux normalised all his results. Secondly, an additional $4^{\circ} \mathrm{C}$ must be subtracted from his data to compensate for the isotopic composition of $-1.00 \%$ PDB of the Early Miocene ocean (see earlier), a factor which in 1967 was not considered to be of major consequence in paleotemperature determinations (e.g., Devereux $1967 \mathrm{~b}$, p. 452). The 2 paleotemperature curves are compared in Fig. 4, and while there are qualitative similarities in their shapes, there are clearly important differences in the magnitude of the absolute temperature drops recorded and in the timing and details of climatic events.

The extent of cooling across the New Zealand Eocene-Oligocene boundary indicated by our curve is similar to that inferred by Hornibrook (1971) from total paleontologic evidence (Fig. 1, curve F) and by Jenkins (1968) from planktic foraminiferal data (Fig. 1, curve F), although their curves span the subtropical-warm temperate climatic zones while ours covers the warm temperate-cool temperate interval. Srinivasan \& Vella (1975) estimated from foraminiferal evidence that the Port Elizabeth-Cape Foulwind area experienced mainly warm temperate conditions during the Late Eocene and Early Oligocene. On the basis of a variety of fossil criteria, Edwards (1968a) postulated generally similar climatic conditions over this interval for the southeastern South Island which, by removing postOligocene transcurrent displacement on the Alpine 
Fig. 4 Comparison of our isotopic temperature curve across the Eocene-Oligocene boundary (see Fig. 3) with that part of Devereux' (1967a) New Zealand Tertiary isotopic climate curve for the same time period. Note that the comparison involves a $5^{\circ} \mathrm{C}$ depression of Devereux' published paleotemperature curve (see text for explanation). The position, character, and time range of fossil materials forming Devereux' isotopic control points are superimposed on the plot (-... planktic foraminifera, - - - . benthic foraminifera, - - oysters, - whole rock bryozoan limestones). Absolute ages from Stevens (1980).

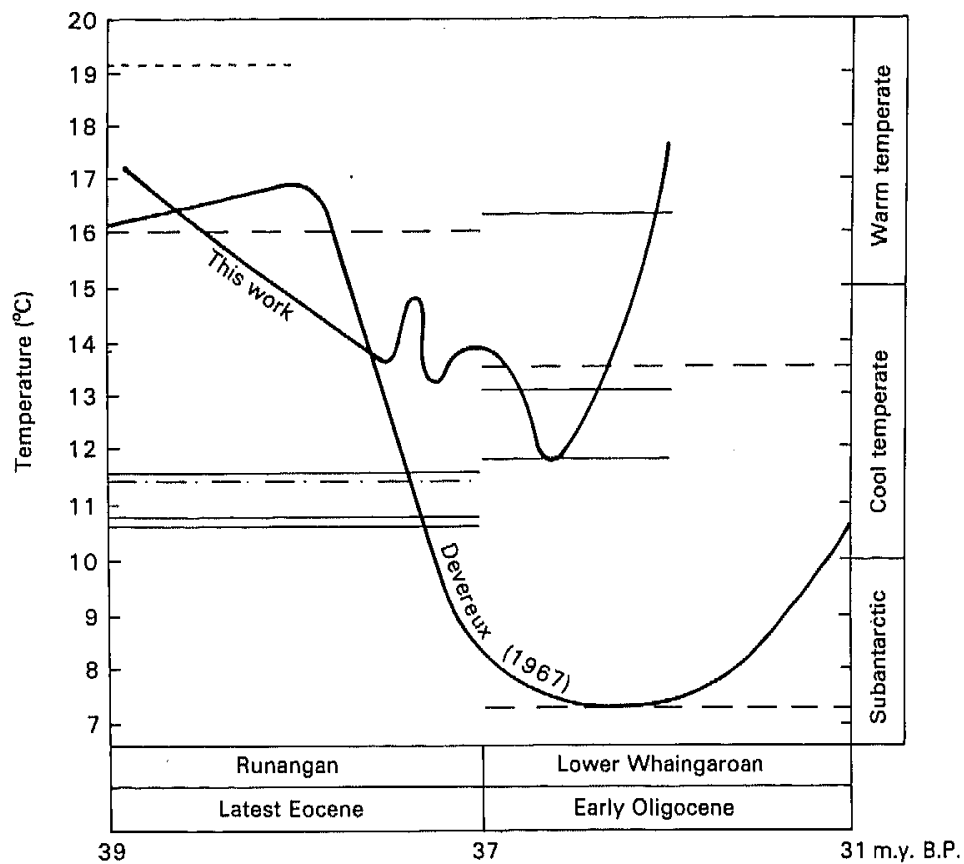

Fault, probably occupied a similar paleolatitude to the Port Elizabeth-Cape Foulwind area at this time (e.g., Carter \& Norris 1976). From calcareous nannofossil distributions, Edwards (1968b; Fig. 1, curve I) also suggested that cool temperate conditions may have been reached in the Early Oligocene, as indicated by the decline of rhabdoliths and braarudosphaerids through the Runangan, and their eventual absence in the Whaingaroan.

The most significant advances in determining worldwide Tertiary marine paleotemperatures have come from the isotopic analysis of foraminifera and calcareous nannofossils in oceanic sediment cores collected by the DV "Glomar Challenger" during the Deep Sea Drilling Project (DSDP) and by the USNS "Eltanin" (e.g., Douglas \& Savin 1975; Margolis et al. 1975, 1977; Savin et al. 1975; Shackleton \& Kennett 1975; Savin 1977; Keigwin 1980). A consistent feature of the isotopic temperature curves reported by these writers is the occurrence of a significant cooling of oceanic waters near the Eocene-Oligocene boundary. A temperature drop of $3-5^{\circ} \mathrm{C}$ is recorded for both subantarctic and equatorial bottom waters and also for subantarctic surface waters, while equatorial surface waters show only a minor change. This suggests that the cause of cooling was primarily a high-latitude surface phenomenon (Margolis et al. 1977; Keigwin 1980). Kennett et al. (1975) related this cooling to a decrease in Antarctic surface-water temperatures to near freezing as a result of the formation of extensive sea ice about the Antarctic continent near the Eocene-Oligocene boundary. Subsequent production of chilled Antarctic bottom waters initiated a thermohaline, deep-oceanic circulation system, similar to that occurring today, and effected a redistribution of significantly colder waters to the world's oceans, causing major global cooling (Kennett \& Shackleton 1976).

However, several workers (e.g., Edwards 1975; Savin et al. 1975; Savin 1977) have emphasised that oceanic bottom water temperatures near the Eocene-Oligocene boundary are probably too warm to be consistent with the development of extensive ice shelves or sea ice about the Antarctic continent, as exists today. Sealevel glaciation must have been limited and restricted to local areas about West Antarctica (Margolis et al. 1977; Savin 1977). Thus, other factors, such as the development of oceanic conditions resulting from the progressive opening of the Australia-Antarctica gap, or astronomical causes, may be additionally responsible for the sudden cooling of Antarctic waters near the Eocene-Oligocene boundary (Margolis et al. 1977). Prior to the separation of the South Tasman Rise (Australia) from Wilkes Land (Antarctica) at about the Eocene-Oligocene boundary (Barker \& Burrell 1977), circilation patterns in the Southwest Pacific were dominantly under the influence of equatorial currents and consequently the Eocene seas were 
characterised by a relatively small latitudinal thermal gradient (e.g., Edwards 1975; Savin 1977; Nelson 1978). Following separation, however, an embryonic circumpolar flow of cool water developed from west to east between AustraliaNew Zealand and Antarctica (e.g., Edwards 1975; Burns 1977). This proto-Circumantarctic Current would have induced at least partial isolation of Antarctic surface waters and accentuated the effects of high-latitude cooling associated with the local production of sea ice about the continent.

Margolis et al. (1977) have reviewed the timing and magnitude of oxygen isotopic temperature changes recorded in deep-sea cores. Following an Early Tertiary warming trend of about $5^{\circ} \mathrm{C}$ to a thermal maximum in the Early-Middle Eocene, both bottom and surface waters exhibit a steady parallel decrease in temperature throughout the remainder of the Eocene. Near the EoceneOligocene boundary there is at first a slight warming and then a sudden cooling by $4-5^{\circ} \mathrm{C}$ in the earliest Oligocene. Surface temperature at DSDP Site 277 on the Campbell Plateau, immediately south of New Zealand, was about $13^{\circ} \mathrm{C}$ in Middle Eocene, about $11^{\circ} \mathrm{C}$ in Late Eocene, and about $7^{\circ} \mathrm{C}$ in Early Oligocene (Shackleton \& Kennett 1975). From estimates of sedimentation rates at this site, Kennett \& Shackleton (1976) inferred that the sudden temperature drop in the earliest Oligocene occurred within a period of about 100000 years, although from a more detailed duplicate isotopic record Keigwin (1980) indicates a maximum duration of 800000 years for this drop. During the remainder of the Oligocene, temperatures increased slightly, but were more stable.

In comparison, our curve for shelf waters exhibits a more steady decline in temperature by about $3^{\circ} \mathrm{C}$ throughout the latest Eocene (Runangan), the same temporary warming at the Eocene-Oligocene boundary, a very sudden temperature drop of about $2^{\circ} \mathrm{C}$ in the earliest Oligocene (basal Whaingaroan), and a subsequent significant warming trend in the late Early Oligocene. Our estimates of absolute water temperature from the Late Eocene through to the earliest Oligocene are on average about $5^{\circ} \mathrm{C}$ higher than those determined by Shackleton \& Kennett (1975) at DSDP Site 277 on the Campbell Plateau, a result which is reasonable considering the $5-10^{\circ}$ latitudinal difference between the 2 areas at this time (Weissel et al. 1977; Nelson 1978). The apparent increase of sea temperatures in the Cape Foulwind region in the late Early Oligocene requires further substantiating by more detailed analyses. If the trend is real, and not short lived, it represents an important departure from the temperature record revealed by the Southern Ocean deep-sea sediment cores. A possible explanation involves the development of significant circumpolar flow south of New Zealand somewhat earlier (say, late Early Oligocene) than has hitherto been generally accepted (e.g., cf. fig. $9 \& 10$, Kennett et al. 1975; cf. fig. $6 \& 7$, Edwards 1975). This would have had the effect of deflecting cool surface waters in the South Tasman Basin more to the east and southeast of New Zealand, and permitting intrusion of warmer subtropical waters south into the Tasman Sea, thereby maintaining cool temperatures in the Southern Ocean while the shelf waters off western South Island were warmed. Alternatively, the temperature amelioration may reflect more local paleogeographic changes of tectonic or eustatic nature which acted so as to reduce the amount of cool water upwelling over the shelf edge or to shift the mean position on the shelf of an offshore warm water current. Stratigraphic variations in the lithology (e.g., Nathan 1975, 1978) and paleontology (e.g., Officers of the Geological Survey 1974; Srinivasan \& Vella 1975) of the Eocene-Oligocene sections could be interpreted in terms of changing water mass characteristics, but such a reconstruction is not attempted here.

Considering the limitations of the isotopic data previously discussed, including the important problem of sampling density (Nelson \& Burns in press), the degree of correlation between our temperature curve and the DSDP curve(s) is at least encouraging and suggests that both shelf and oceanic environments responded more or less simultaneously to the same temperature-controlling event(s). A parallel situation has been documented for Oligocene unconformities (Carter \& Landis 1972). These are widespread in deep-sea sediment sequences and are attributed to enhanced seafloor erosion caused by Antarctic bottom water production following the major climatic cooling near the Eocene-Oligocene boundary (e.g., Kennett et al. 1972, 1975; Kennett \& Shackleton 1976; Berggren \& Hollister 1977). However, Carter \& Landis (1972) have shown that the effects of enhanced Oligocene circulation are also recorded widely by unconformities in shallow shelf strata in the Southwest Pacific, and they coined the name "Marshall Paraconformity" for these Oligocene stratigraphic breaks. Interestingly, although unconformities are not evident in the mudstones at Cape Foulwind, foraminiferal characteristics led Srinivasan \& Vella (1975) to postulate generally quiet water and slow sedimentation conditions during the Late Eocene (Runangan), but more turbulent water and faster sedimentation in the Early Oligocene (Whaingaroan), despite the fact that water depth remained similar throughout. 


\section{ACKNOWLEDGMENTS}

We thank Professor Paul Vella (Victoria University of Wellington, Wellington) for providing splits of samples for analysis, Dr Chris Hendy (University of Waikato, Hamilton) for assistance with isotopic analysis procedures, and Dr Peter Hodder (University of Waikato, Hamilton) for comments on a manuscript copy of the paper. D Nelson gratefully acknowledges the facilities and hospitality of the Department of Geological Sciences, University of British Columbia, Canada, during the writing of this paper.

\section{REFERENCES}

Barker, P. F.; Burrell, J, 1977: The opening of Drake Passage. Marine geology 25:15-34

Berggren, W. A. 1972: A Cenozoic time-scale-some implications for regional geology and paleobiogeography, Lethaia $5: 195-215$.

Berggren, W. A.; Hollister, C. D. 1977: Plate tectonics and paleocirculation-commotion in the ocean. Marine geology $38: 11-48$.

Berggren, W. A.; van Couvering, J. A. 1974: The Late Neogene-biostratigraphy, geochronology and palaeoclimatology of the last $15 \mathrm{~m}$.y. in marine and continental sequences. Palaeogeography, palaeoclimatology, palaeoecology $16: 1-216$.

Beu, A. G.; Maxwell, P. A. 1968: Molluscan evidence for Tertiary sea temperatures in New Zealand: a reconsideration. Tuatara $16: 68-74$.

Blattner, P.; Hulston, J. R. 1978: Proportional variations of geochemical $\delta^{18} \mathrm{O}$ scales-an interlaboratory comparison. Geochimica et cosmochimica acta 42 $59-62$.

Burns, Derek A. 1977: Major features of oceanographic development of the southeast Indian and southwes Pacific oceans interpreted from microfossil evidence. Marine geology 25: 35-60.

Burns, David A. 1980: Aspects of the carbon and oxygen stable isotope geochemistry of some New Zealand Cenozoic calcareous sediments. Unpublished M.Sc. thesis, lodged in the Library, University of Waikato, Hamilton, New Zealand.

Carter, R. M.; Landis, C. A. 1972: Correlative Oligocene unconformities in southern Australasia. Nature physical science 237: 12.

Carter, R. M.; Norris, R. J. 1976: Cainozoic history of southern New Zealand: an accord between geological observations and plate-tectonic predictions. Earth and planetary science letters 31 $85-94$.

Craig, H. 1957: Isotopic standards for carbon and oxygen and correction factors for mass-spectrometric analysis of carbon dioxide. Geochimica et cos mochimica acta 12 : 133-149.

1965: The measurement of oxygen isotope paleotemperatures. Pp. 1-24 in: Spoleto Conference on Stable Isotopes in Oceanographic Studies and Paleotemperatures, proceedings 3. Pisa, Italy Consiglio Nazionale delle Recherche, Laboratoria di Geologia Nucleare.

Dawson, J. W. ed. 1968: The Tertiary climate of New Zealand. Tuatara 16:1-82.
Devereux, I. 1967a: Oxygen isotope paleotemperature measurements on New Zealand Tertiary fossils. New Zealand journal of science 10:988-1011.

1967b: Oxygen isotope palaeotemperature measurements on two Tertiary deep-water coral thickets from Wairarapa, New Zealand. Palaeogeography, palaeoclimatology, palaeoecology 3: $447-455$

Douglas, R. G.; Savin, S. M. 1975: Oxygen and carbon isotope analyses of Tertiary and Cretaceous microfossils from the Shatsky Rise and other sites in the North Pacific Ocean. Pp. 509-520 in: Larsen, R. L.; Moberly, R. Initial reports of the Deep Sea Drilling Project 32. Washington, D.C., U.S. Government Printing Office.

Edwards, A. R. 1968a: Marine climates in the Oamaru district during late Kaiatan to early Whaingaroan time. Tuatara $16: 75-79$

1968b: The calcareous nannoplankton evidence for New Zealand Tertiary marine climate. Tuatara $16: 26-31$.

1975: Southwest Pacific Cenozoic paleogeography and an integrated Neogene paleocirculation model. Pp. 667-684 in: Andrews, J. E.; Packham, G. Initial reports of the Deep Sea Drilling Project 30: Washington, D.C., U.S. Government Printing Office.

Fleming, C. A. 1962: New Zealand biogeography. A paleontologist's approach. Tuatara 10:53-108. 1979: The geological history of New Zealand and its life. Auckland University Press. $141 \mathrm{p}$.

Grinstead, M. J. 1977: A study of the relationship between climate and stable isotope ratios in tree rings. Unpublished $\mathrm{Ph} . \mathrm{D}$. thesis, lodged in the Library, University of Waikato, Hamilton, New Zealand.

Hecht, A. D. 1976: The oxygen isotope record of foraminifera in deep sea sediment. Pp. 1-43 in: Hedley, R. H.; Adams, C. G. Foraminifera. Vol. 2. London, Academic Press, 265 p.

Hornibrook, N. de B. 1967: New Zealand Tertiary microfossil zonation, correlation and climate. Pp. 29-39 in: Hatai, $\mathrm{K}$. ed. Tertiary correlations and climatic changes in the Pacific. Sendai, Sasaki Printing and Publishing Co,, 102 p.

1968: Distribution of some warm water benthic foraminifera in the New Zealand Tertiary. Tuatara $16: 11-15$

1971: New Zealand Tertiary climate. New Zealand Geological Survey report 47. $19 \mathrm{p}$.

1978: Tertiary climate. Pp. 436-443 in: Suggate, R. P.; Stevens, G. R.; Te Punga, M. T. ed. The geology of New Zealand. Wellington, Government Printer, 2 vols, $820 \mathrm{p}$.

Hornibrook, N. de B.; Edwards, A. R. 1971: Integrated planktonic foraminiferal and calcareous nannoplankton datum levels in the New Zealand Cenozoic. Pp. 649-657 in: Farinacci, A, ed. Proceedings Second Planktonic Conference. Roma 1970.

Jenkins, D. G. 1968: Planktonic Foraminiferida as indicators of New Zealand Tertiary paleotemperatures. Tuatara 16: $32-37$.

Keigwin, L. D. 1980: Palaeoceanographic change in the Pacific at the Eocene-Oligocene boundary. Nature $287: 722-725$ 
Kennett, J. P.; Shackleton, N. J. 1976: Oxygen isotopic evidence for the development of the psychrosphere $38 \mathrm{M}$ yr ago. Nature $260: 513-515$.

Kennett, J, P.; Burns, R. E.; Andrews, J. E.; Churkin, M.; Davies, T. A.; Dumitrica, P.; Edwards, A. R.; Galehouse, J. S.; Packham, G. H.; van der Lingen, G. J. 1972: Australian-Antarctic continental drift, palaeocirculation changes and Oligocene deep-sea erosion. Nature physical science $239: 51-55$.

Kennett, J. P.; Houtz, R. E.; Andrews, P. R.; Edwards, A. R.; Gostin, V. A.; Hajos, M.; Hampton, M.; Jenkins, D. G.; Margolis, S. V.; Overshine, A. T.; Perch-Nielsen, K. 1975: Cenozoic paleoceanography in the Southwest Pacific Ocean, Antarctic glaciation, and the development of the CircumAntarctic current. Pp. 1155-1169 in: Kennett, J. P.; Houtz, R. E. Initial reports of the Deep Sea Drilling Project 29. Washington, D.C., U.S. Government Printing Office.

Keyes, I. W. 1968: Cenozoic marine temperatures indicated by the scleractinian coral fauna of New Zealand. Tuatara 16: $21-25$.

Margolis, S. V.; Kennett, J. P. 1971: Cenozoic paleoglacial history of Antarctica recorded in subantarctic deep-sea cores. American joumal of science 271 : $1-36$.

Margolis, S. V.; Kroopnick, P. M.; Goodney, D. E.; Dudley, W. C.; Mahoney, M. E. 1975: Oxygen and carbon isotopes from calcareous nannofossils as paleoceanographic indicators. Science 189: paleoceariog

Margolis, S. V.; Kroopnick, P. M.; Goodney, D. E. 1977 : Cenozoic and Late Mesozoic paleoceanographic and paleoglacial history recorded in circumAntarctic deep-sea sediments. Marine geology $25: 131-147$

McQueen, D. R.; Mildenhall, D. C.; Bell, C. J. E. 1968: Paleobotanical evidence for changes in the Tertiary climates of New Zealand. Twatara $16: 49-56$.

Mook, W. G. 1968: Geochemistry of the stable carbon and oxygen isotopes of natural waters in the Netherlands. Unpublished Ph.D. thesis, University of Groningen, Netherlands.

Nathan, S. 1975: Sheets S23 \& S30-Foulwind and Charleston (1st ed.). Geological map of New Zealand 1:63 360. Map (1 sheet) and notes (20 p.). Wellington, Department of Scientific and Industrial Research.

- 1978: Sheet S44-Greymouth (1st ed.). Geological map of New Zealand 1:63 360. Map (1 sheet) and notes (36 p.). Wellington, Department of Scientific and Industrial Research.
Nelson, C. S. 1978: Temperate shelf carbonate sediments in the Cenozoic of New Zealand. Sedimentology $25: 737-771$.

Nelson, C. S.; Burns, D. B. (in press): Effect of sampling interval on the reliability of oxygen isotopic paleotemperatures-an example from the New Zealand Early Miocene. New Zealand journal of geology and geophysics.

Officers of the Geological Survey 1974: Outline of the paleontology of the Greymouth district. New Zealand Geological Survey report 67:61 p.

Savin, S. M. 1977: The history of the earth's surface temperature during the past 100 million years. Annual review of earth and planetary sciences 5 . $319-355$

Savin, S. M.; Douglas, R. G.; Stehli, F. G. 1975: Tertiary marine paleotemperatures. Geological Society of America bulletin 86: 1499- 1510 .

Shackleton, N. J. 1967: The measurement of paleotemperatures in the Quaternary era. Unpublished Ph.D thesis, University of Cambridge, England.

- 1974: Attainment of isotopic equilibrium between ocean water and benthonic foraminifera genus Uvigerina: isotopic changes in the ocean during the last glacial. Pp. 203-209 in: C.N.R.S Colloque 219. Les Methodes quantitative d'etudes des variations du climat au cours du Pléistocène.

Shackleton, N. J.; Kennett, J. P. 1975: Paleotemperature history of the Cenozoic and the initiation of Antarctic glaciation: oxygen and carbon isotope analyses in DSDP Sites 277,279 and 281 . Pp. 743 755 in: Kennett, J. P.; Houtz, R. E. Initial reports of the Deep Sea Drilling Project 29. Washington, D.C. U.S. Government Printing Office.

Smith, P. B.; Emiliani, C. 1968: Oxygen isotope analysis of Recent tropical Pacific benthonic foraminifera. Science 160: $1335-1336$.

Srinivasan, M. S. 1965: Studies in Late Eocene and Early Oligocene foraminifera of New Zealand. Unpublished Ph.D. thesis, lodged in the Library, Victoria University of Wellington, Wellington, New Zealand.

Srinivasan, M. S.; Vella, P. 1975: Upper Eocene-Lower Oligocene benthonic foraminifera, Port Elizabeth and Cape Foulwind, New Zealand. New Zealand journal of geology and geophysics $18: 21-37$.

Stevens, G. R. 1980: Geological time scale. Geological Society of New Zealand wall chart.

Weissell, J. K.; Hayes, D. E.; Herron, E. M. 1977: Plate tectonic synthesis: the displacements between Australia, New Zealand, and Antarctica since the Late Cretaceous. Marine geology $25: 231-277$. 